\title{
PAMSWAKARSA DALAM KONFLIK AGRARIA DI LAMPUNG: ANTARA KEPENTINGAN PERUSAHAAN, NEGARA, DAN MASYARAKAT
}

\author{
PAMSWAKARSA IN AGRARIAN CONFLICT IN LAMPUNG: \\ BETWEEN THE INTEREST OF THE COMPANY, THE STATE, AND \\ THE COMMUNITY
}

\author{
Gita Karisma $^{1}$, Iwan Sulistyo ${ }^{2}$, Fitri Juliana Sanjaya ${ }^{3}$, Khairunnisa Simbolon ${ }^{4}$ \\ 1HI Universitas Lampung; gita.uai@gmail.com \\ 2HI Universitas Lampung; iwan.sulistyo@ fisip.unila.ac.id \\ 3HI Universitas Lampung; sanjayafitrijuliana@gmail.com \\ 4Dosen HI Universitas Lampung; khairunnisasimbolon90@gmail.com
}

Dikirim 4 Januari 2021, Direvisi 12 Maret 2021, Disetujui 29 Maret 2021

\begin{abstract}
Abstrak: Penelitian ini fokus pada peran pamswakarsa yang dibentuk perusahaan dalam konflik agraria di Lampung Indonesia. Dengan menggunakan penelitian kualitatif melalui metode interview dan studi pustaka, penelitian ini menemukan bahwa pamswakarsa dapat dikategorikan sebagai paramiliter. Pamswakarsa eksis saat terjadi konflik namun peran pamswakarsa nyatanya tidak cukup berkontribusi dalam menciptakan perdamaian sebagaimana mandat Peraturan Pemerintah no 43 tahun 2012. Pam swakarsa memiliki payung hukum di Indonesia namun tidak ada pihak yang dapat bertanggung jawab mengenai dimana posisi dan peran mereka sesungguhnya.
\end{abstract}

Kata kunci: Lampung, kekerasan, konflik, paramilitary, pam swakarsa, perusahaan.

\begin{abstract}
This research aims to explore pamswakarsa which was created by corporation and its position on on agrarian conflict in Lampung Province, Indonesia. By using qualitative approach through the methods of interviews and utilizing several related documents, this research finds that pamswakarsa is assumed as paramilitary. Pamswakarsa itself emerged while conflict is existing. It is not relavant enough to support the effort in achieving order and peaceful, as was legally mandated by the regulation from The Indonesian National Police through government regulation Number 43 the Year of 2012. Pamswakarsa tends to be involved in conflict and even has been the new actor/perpretrator against society
\end{abstract}

Keywords: Conflict, corporation, Lampung, pam swakarsa, paramilitary, violent

\section{PENDAHULUAN}

Negara menghadapi beragam ancaman yang tidak selalu datang dari luar, tetapi juga berasal dari dalam, seperti konflik internal. Konflik internal dapat berupa konflik horizontal dan vertikal termasuk konflik etnis dan separatisme. Semuanya cukup mengancam keamanan manusia, bahkan dapat pula mengancam kelangsungan dan keutuhan Indonesia sebagai negara-bangsa.

Dalam konteks tersebut, konflik agraria dipandang sebagai salah satu konflik penting yang cukup sering terjadi, di samping beberapa konflik lain seperti konflik ideologi, politik, ekonomi, sosial, dan budaya dan persoalan Suku, Agama, Ras, dan Antargolongan (SARA). Dalam sejarahnya, peristiwa konflik agraria terus meningkat sepanjang waktu. Konsorsium Pembaruan Agraria (KPA) mencatat, selama tahun 2017 telah terjadi 659 konflik agraria dengan luasan mencapai 520.491,87 hektar bahkan jumlah konflik agraria meningkat 50 persen dibandingkan dengan tahun 2016 yang berjumlah 450 konflik dan dengan tahun 2015 sebanyak 252 (KPA, 2017).

Menariknya, konflik agraria tidak hanya melibatkan aktor negara dan masyarakat, tetapi sering juga 
menghadirkan perusahaan sebagai aktor utama. Provinsi Lampung menjadi salah satu daerah di Indonesia yang sering mengalami konflik; salah satunya bersumber dari sengketa lahan dan agraria. Sebagaimana data yang bersumber dari direktur LBH kota Bandarlampung, Provinsi Lampung memiliki beberapa konflik, salah satunya ialah konflik agraria. Kasus agraria yang ditangani LBH kurang lebih sebanyak 84 kasus yang sebagian besar belum selesai (Kompas, 2012).

Pada Oktober 2016, misalnya telah terjadi bentrok antara warga dengan perusahaan di Tulang Bawang Lampung. Pada saat kerusuhan terjadi, Perusahaan melibatkan peran

Pengamanan (Pam) Swakarsa. Pam Swakarsa Perusahaan inilah yang kemudian bentrok dengan warga dan serikat tani. Fenomena Pamswakarsa ini seringkali hadir dalam konflik di Lampung. Beberapa perusahaan semisal PT Bangun Nusa Indah Lampung, PT Prima Alumga (PPA) dan PT. Silva Inhutani, PT Sumber Wangi Alam (SWA) di Mesuji dan lainnya, membentuk dan melibatkan Pamswakarsa dalam operasional perusahaan.

Pam swakarsa di Indonesia dibina dengan pendidikan dan pelatihan personel yang mengarah kepada bentuk paramiliter. Paramiliter, sebagaimana pasukan bersenjata di seluruh dunia, menggunakan tipe teknologi yang sama, seperti training courses, bentuk komando, pola operasi, metode rekruitmen yang memiliki kemiripan satu sama lain (Peter B. Kraska and Victor E. Kappeler, 1997: 2). Sejarah memperlihatkan bahwa paramiliter eksis di negara fasis-komunis, dan seringkali menyebabkan benturan dengan militer negara ataupun masyarakat. Di era tersebut, muncul formasi politik bersenjata yang diselenggarakan di negara-negara fasis, yang kemudian kian berkembang pada tahun 1950 dalam formasi mirip dalam perang dekolonisasi dan konflik pascakolonial (Trevor N Dupuy, 1993: 2 dalam Robert Gerivart) .
Di Indonesia, Pam Swakarsa diatur salah satunya dalam PP No. 43 tahun 2012. Pam Swakarsa memiliki peran bersama dengan Polri untuk menjaga ketertiban dan keamanan. Kenyataanya, Pamswakarsa bentukan Perusahaan justru bentrok dengan warga. Dengan begitu, menarik untuk mengkaji posisi pam swakarsa di Indonesia, khususnya bentukan Perusahaan. Mengapa Paramiliter masih diperlukan keberadaannya padahal negara Indonesia memiliki Polri dalam urusan ketertiban dan keamanan nasional, dan TNI dalam urusan pertahanan. Bagaimana peran pam swakarsa dalam konflik di Tulang Bawang?

Tulisan ini bertujuan menjelaskan format Pam Swakarsa yang dibentuk oleh PT X apakah telah sejalan dengan aturan serta menganalisis posisi dan peran Pam Swakarsa dalam situasi konflik antara Perusahaan, Negara dan Masyarakat. Kehadiran Pam swakarsa ini di satu sisi dapat membantu menciptakan keamanan. Akan tetapi, di sisi lain, tidak mustahil dapat memperburuk situasi konflik agraria yang kerap terjadi di Provinsi Lampung. Negara demokratis seperti Indonesia selayaknya dapat memperhatikan kedudukan paramiliter. Apakah paramiliter cukup dibutuhkan terutama dalam situasi konflik agrarian dan apakah pamswakarsa memiliki andil dalam upaya menciptakan ketertiban dan keamanan.

Paramiliter merupakan istilah yang belum dirumuskan sampai tahun 1930-an, ketika menetapkan kemunculan formasi politik bersenjata diselenggarakan di negara-negara fasis; kemudian dikembangkan pada tahun 1950 untuk menggambarkan formasi semacam itu dalam perang dekolonisasi dan konflik pascakolonial (Trevor N Dupuy, 1993: 2 dalam Robert Gerivart). Tetapi formasi paramiliter memiliki sejarah yang jauh lebih tua, baik sebagai milisi lokal, gerakan gerilya atau tambahan bersenjata untuk kekuatan ketertiban.

Paramilitarisme adalah ciri menonjol dalam semua konflik yang terjadi di Eropa 
pasca Perang Dunia I. Paramiliter ini biasanya terjadi dalam situasi kekosongan (vacum) pada masa transisi atau negara pecahan yang ditinggalkan negara sentralnya karena hancur; pada kesempatan lain paramiliter berfungsi sebagai tambahan yang mensupport kekuasaan negara; di lain pihak paramiliter dikerahkan melawan negara (Robert Gerivarth, John Horne, 2012:2). Dengan berspekulasi bahwa polisi bisa menjadi apa pun kecuali paramiliter, hal ini menolak adanya ikatan yang melekat - secara historis, politik dan sosiologis antara polisi dan militer (Bittner1970; Enloe 1980). AustinTurk (1982: 21) memperjelas hubungan yang melekat ini dengan membedakan pembentukan pasukan polisi sipil di negara berkembang (Peter B. Kraska and Victor E. Kappeler, 1997: 2).

Salah satu defenisi yang dapat dirujuk tentang konsep paramilitary ialah dari Department of Defense Dictionary of Military and Associated Terms yang menyebutkan bahwa paramilitary forces merupakan "armed forces or groups distinct from the conventional armed forces of any country, but resembling them in organization, equipment, training, or mission." [terjemahan bebas: angkatan bersenjata atau kelompok yang berbeda dari angkatan bersenjata konvensional negara manapun, tetapi menyerupai mereka dalam hal organisasi, peralatan, pelatihan, atau misi]. ${ }^{1}$ Literatur yang lain mengungkapkan bahwa "a force is classified as paramilitary if it has a degree of military capability, although strictly speaking it is not a branch of an armed service." [terjemahan bebas: suatu kekuatan diklasifikasikan sebagai paramiliter jika ia memiliki tingkat kemampuan militer, walaupun secara tegas ia bukan cabang dari suatu angkatan

\footnotetext{
${ }^{1}$ Department of Defense of the United States of America, Department of Defense Dictionary of Military and Associated Terms, Joint Chiefs of Staff, USA, as of September 2018, hlm. 179; tersedia juga
}

bersenjata]. (John Andrade, 1985, halaman ix).

Perusahaan yang membentuk Pamswakarsa memiliki kepentingan bisnis. Selain itu hubungan pamswakarsa dan perusahaan ini dalam perspektif Marxisme sering disebut sebagai penggambaran dari proses kekerasan akumulasi modal oleh perusahaan melalui kelompok paramiliter (Harvey, 2004).

Isu paramiliter terus mengalami perkembangan di Indonesia. Tulisan mengenai Pam Swakarsa yang dibentuk perusahaan masih cukup sulit ditemui. Artikel paramiliterisme di Indonesia semisal ditulis oleh Saafroedin Bahar dengan artikel yang berjudul Kajian Awal Tentang Keterkaitan Pasukan Paramiliter dan Militer dengan Faham Militerisme dan Fasisme di Indonesia. Menurutnya, dalam rangka menegakan demokrasi yang lebih beradab, baik dikalangan sipil maupun militer, ada sikap ambivalen yang belum pernah dapat diselesaikan tentang peran dan hubungan antara satuan paramiliter dan militer (Safroedin Bahar, 2000: 67). Di satu sisi, ada kecendrungan sipil ingin tetap membentuk dan menggerakan satuan paramiliter partai meski secara formal mereka menolak peranan politik militer, namun tetap menambah satuan paramiliter dan secara sadar merancang satuan khusus dengan uniform bahkan gemblengan militeristik (Safroedin Bahar, 2000: 67). Hal ini didorong keterbatasan personil dan dana, pasukan paramiliter dianggap relatif lebih murah dan terkadang efektif (Safroedin Bahar, 2000: 67). Dalam artikel ini, Saafroedin juga mengesankan bahwa kecendrungan mobilisasi sipil menggunakan atribut militer, membentuk pasukan paramiliter dan menggunakannya untuk kepentingan politik dapat dipandang sebagai refleksi ideologi militerisme.

di

http://www.jcs.mil/Portals/36/Documents/Doctrine/ pubs/dictionary.pdf diakses pada 11 November 2018. 
Selain itu Matt McDonald dan Lee Wilson, dua orang peneliti pada the University of Queensland, Australia, melalui artikelnya yang berjudul Trouble in paradise: Contesting security in Bali, menganalisis fenomena paramiliter di Bali yang mereka sebut dengan militia group. Melalui analisis secara etnografis, keduanya menjelaskan bentuk milita group dengan beberapa ormas di Bali. Trends paramiliter ini muncul sejak pasca kejatuhan Orde Baru dan kemudian menjadi formal melalui Perda No. 3 Tahun 2001. McDonald dan Wilson berargumen bahwa keberadaan paramiliter ini pada awalnya didukung untuk merespon ancaman terorisme pasca-Bom Bali. Namun, oleh kedua peneliti, keberadaan paramiliter tersebut dianggap dapat menjadi tantangan bagi format pengamanan resmi militer negara (Matt Mcdonald and Lee Wilson, 2017: 241-258).

\section{METODOLOGI}

Penelitian ini menggunakan pendekatan kualitatif yang mengarah pada jenis studi kasus analisis situasi. Kasus yang diambil adalah Konflik antara PT X dengan masyarakat di Lampung. Peneliti mencoba mempelajari berbagai sudut pandang, dengan teknik pengumpulan data melalui studi pustaka dan wawancara mendalam, diantaranya dengan warga setempat, organisasi Serikat Tani, dan beberapa personil paramiliter akif dan non aktif, Pemerintah Daerah, dan Kepolisian setempat. Berbagai jenis data diperoleh baik dalam bentuk data primer maupun data sekunder. Data primer didapat dari wawancara serta data sekunder diperoleh dari catatan kronologi dari Serikat Tani, website KPA, dan sumber lainnya. Sedangkan tekhnik analisa data yang dipakai adalah analisis konten.

\section{HASIL DAN PEMBAHASAN}

Pada bagian ini akan dijelaskan mengenai peran pamswakarsa dalam menyokong perdamaian dalam konflik agraria. Sebelum membahas kaitan antara pamswakarsa dan perdamaian maka akan dijelaskan lebih dulu mengenai ciri pamswakarsa sebagai paramiliter dan hubungannya dengan perusahaan.

Pam Swakarsa menurut UndangUndang berada di bawah kontrol dan koordinasi Kepolisian Republik Indonesia. Dalam kasus konflik di Lampung, Pam Swakarsa dikoordinir oleh Perusahaan seperti PT X, PT. Y serta PT Z. Pam Swakarsa ini bertugas untuk melakukan pengamanan terhadap kelangsungan dan kepemilikan asset Perusahaan. Perusahaan sebetulnya telah memiliki security atau satpam yang diberikan gaji regular tiap bulannya. Uniknya, sejumlah Perusahaan juga memberdayakan pengamanan lainnya semacam Pam Swakarsa.

Sebagai salah satu contoh, dapat ditemukan 3 jenis pengamanan yang terkait PT X, pertama, Security Perusahaan atau satpam, yang bekerja setiap hari dan diberikan gaji setiap bulan oleh perusahaan. Kedua, Pam Swakarsa Areal/Pengamanan Areal, tugasnya adalah berjaga keliling di sepanjang lahan perusahaan dan digaji perhari kurang lebih Rp.83.000. Hingga tahun 2018, tercatat ada sekitar 13 orang anggota tetap Pam Swakarsa Areal, yang terdiri dari 3 suku Jawa, 5 orang Lampung, 4 orang Mesuji, dan 1 orang Bali. Ketiga, yang paling menarik adalah Pam Swakarsa Khusus yakni pasukan pengamanan yang hanya ditugaskan saat kondisi tertentu, seperti situasi konflik.

Pam Swakarsa khusus dibentuk untuk merespon situasi krisis yang dianggap perlu oleh perusahaan, bahkan anggota nya juga berasal dari berbagai kalangan tanpa ada kriteria khusus, termasuk dari Pam Swakarsa areal. Saat ditengarai ada gerakan tuntutan dari warga, maka Pam Swakarsa ini dikumpulkan oleh Perusahaan. Anggota 
Pam Swakarsa diberikan kompensasi rerata mulai Rp. 100.000- 150.000. Pada saat bentrok terjadi pada Oktober 2016, anggota Pam Swakarsa diberikan kompensasi sebesar Rp.150.000/perhari. Pembayaran biasanya dilakukan perminggu. Para anggota Pam Swakarsa ini umumnya tidak mengetahui pihak mana yang menghubungi mereka, namun mereka meyakini bahwa pihak yang menghubungi adalah dari perusahaan. Sebagian dari mereka menjadi anggota Pam dengan melamar secara khusus, namun kebanyakan melalui ajakan dan bersifat accidental.

Para anggota Pam Swakarsa tidak lain merupakan warga lokal, bahkan dari korban penggusuran, sehingga antara masyarakat, anggota Pam Swakarsa, dan anggota Serikat Tani tidak jarang adalah tetangga dan saling mengenal satu sama lain. Di luar masa konflik, hubungan diantara keduanya terjalin baik. Pihak Serikat Tani mengatakan tetap harus menjaga hubungan baik meski juga disisi lain harus berhatihati dengan anggota Pam Swakarsa (Wawancara Tim Penelitian, September 2018).

Umumnya, warga yang menjadi anggota Pam Swakarsa didasari oleh motif ekonomi. Terbatasnya lapangan pekerjaan dan kemiskinan menyebabkan beberapa warga tertarik menjadi anggota Pam Swakarsa. Beberapa yang lain tidak berminat bergabung menjadi anggota Pam Swakarsa atas dasar idealisme dan resiko kerja yang menurut mereka berat dan tidak sebanding dengan kompensasi yang diterima.

Pam Swakarsa dapat dikatakan merupakan mobilisasi kekuatan yang berada diantara polisi sipil dan paramiliter. Sebagaimana John Andrade telah ungkapkan bahwa suatu kekuatan diklasifikasikan sebagai paramiliter jika ia memiliki tingkat kemampuan militer, walaupun secara tegas ia bukan cabang dari suatu angkatan bersenjata (John Andrade, 1985, halaman ix). Meski anggota Pam Swakarsa dalam kasus ini tidak dibekali pelatihan militer dan persenjataan yang mumpuni, namun sebagaimana bentuk organisasi militer, pam swakarsa ini memiliki komandan dan lapis-lapis tertentu. Bahkan anggota diperbolehkan membawa alat bela diri masing-masing. Anggota Pam Swakarsa ditemukan membawa celurit, parang, dan benda tumpul lainnya, bahkan salah satu warga mengatakan pernah melihat salah satu anggota pam swakarsa membawa pistol (Wawancara Tim Penelitian, September 2018). Anggota Pam Swakarsa setiap satu kali dalam seminggu diwajibkan mengikuti apel. Beberapa latihan dan himbauan disampaikan pada saat apel.

Jika meninjau dari sisi perusahaan, memiliki alat keamanan seperti Pam Swakarsa adalah suatu kebutuhan. Menurut PP RI No 43 tahun 2012, Pam Swakarsa berada di bawah koordinasi Kepolisian RI. Sehingga jelas bahwa paramiliter adalah bagian dari sector public. Di satu sisi, penggunaan paramiliter oleh aktor nonnegara yaitu private sector seperti perusahaan merupakan representasi keterkaitan antara sektor swasta dan publik yang menandakan ekonomi politik berjalan sehat di mana kebebasan kekuasaan pribadi (privat) adalah yang tertinggi sehingga mengarah pada liberalisme ekonomi.(Brown \& Ainley, 2009)

Di sisi lain, dari garis pemikiran yang lebih kritis, pemberian wewenang kemanan dengan penggunaan paramiliter kepada aktor non-negara (privat) terutama pelaku usaha/perusahaan adalah berbahaya karena kepentingan perusahaan bersinggungan langsung dengan kepentingan penduduk setempat (Bennett, 2002). Penduduk memiliki hak ekonomi dan kesejahteraan yang ironisnya seringkali terpinggirkan karena kepentingan ekonomi perusahaan, contohnya dalam konflik agraria. Lebih jauh, ketika terjadi konflik antara Perusahaan dan Warga terkait lahan, maka Perusahaan sulit menempatkan diri mereka. Kemudian muncul perdebatan mengenai hak bisnis yang bertanggung jawab atau 
tanggung jawab sosial perusahaan kepada masyarakat. Akan tetapi, perusahaan seringkali sulit untuk menjaga tanggung jawab ini, disinilah negara dibutuhkan sebagai pihak penengah dalam upaya menciptakan perdamaian.

Negara Indonesia hadir dengan memberikan wadah hukum bagi Pam Swakarsa. Berdasarkan PP RI No 43 tahun 2012 Pengamanan Swakarsa yang selanjutnya disingkat Pam Swakarsa adalah suatu bentuk pengamanan yang diadakan atas kemauan, kesadaran, dan kepentingan masyarakat sendiri yang kemudian memperoleh pengukuhan dari Kepolisian Negara Republik Indonesia. Dalam PP ini, khususnya Pasal 3, disebutkan bahwa Polri dibantu oleh Pansus, PPNS, dan Pam Swakarsa menjalankan fungsi kepolisian. Bahkan pada Bab 2 Pasal 6 disebutkan secara khusus bahwa pam swakarsa bertugas menjaga keamanan dan ketertiban di lingkungannya secara swakarsa guna mencegah terjadinya gangguan keamanan dan ketertiban.

Selain itu, dengan mengacu kepada isi peraturan Kepala Kepolisian Negara Republik Indonesia Nomor 24 Tahun 2007 tentang Sistem Manajemen Pengamanan Organisasi, Perusahaan, dan atau Instansi/Lembaga Pemerintah, Pam Swakarsa adalah bentuk paramiliter. Pam swakarsa yang diakui kemudian secara gamblang disebutkan dalam pasal 7 adalah Satpam. Satpam merupakan kesatuan sah menurut peraturan ini. Dalam pasal 14 satpam juga mesti memenuhi persyaratan seperti, bebas narkotika, lulus psikotest, lulus tes kesehatan, skck, berpendidikan minimum SMU, dan lainnya. Sedangkan Pam Swakarsa bentukan PT X umumnya dibentuk reaktif dan spontan, sehingga kebanyakan terdiri dari "jagoan" desa atau yang memiliki keberanian semata. Oleh karenanya, Kepolisian Resort menyebut tipe ketiga dari Pam Swakarsa dalam konflik $\mathrm{X}$ adalah mobilisasi massa (Wawancara Tim Penelitian, November 2018).
Pam swakarsa memang secara jelas diakui dan diberi ruang oleh negara melalui aturan PP dan Peraturan Kepolisisan. Namun, faktanya masih muncul pam swakarsa yang statusnya belum jelas bahkan tidak diakui oleh Kepolisian Negara. Nyatanya, aturan yang dibuat oleh Pemerintah ini memberi celah kepada berbagai pihak di Indonesia seperti perusahaan dan organisasi masyarakat untuk dapat membentuk pasukan paramiliter atas alasan sah menurut aturan perundangan. Apabila kemudian sebagian Pam swakarsa dianggap bukanlah sebagaimana pam swakarsa dalam definisi menurut aturan yang telah dibuat, dan bahkan disebut sebagai mobilisasi masa, maka yang perlu digarisbawahi bahwa dimana "Pam Swakarsa" perusahaan ini ditempatkan dan siapa yang bertanggung jawab atas mereka.

\section{PERAN PAM SWAKARSA: PELUANG KEKERASAN DARI NEGARA KE PERUSAHAAN}

Konflik Perusahaan dengan warga tani yang dimulai setidaknya dari tahun 1991 telah menempatkan Pam swakarsa sebagai actor baru dalam konflik. Pam swakarsa memiliki peran sebagai perwujudan kepentingan perusahaan ditengah konfigurasi masyarakat dan negara. Konflik menjadi kian berlarut karena upaya penyelesaian seringkali mengalami kebuntuan. Pada awal terjadi konflik, masyarakat sudah tidak dibiarkan tau dengan jelas status kepemilikan tanah perusahaan maupun kompensasi ganti rugi bagi mereka. Di sisi lain, bagi pihak seperti Kepolisian sulit bagi mereka menempatkan diri dimana di satu sisi ada tanggung jawab melindungi dan menjaga ketertiban dan keamanan bagi masyarakat, namun di sisi lain perusahaan memiliki hak usaha melalui HGU yang telah dikeluarkan BPN. Begitupun dengan pemerintah Kabupaten setempat, posisi Pemerintah Kabupaten memiliki dua peran diantaranya mengerti kebutuhan masyarakat dan secara 
bersamaan juga mampu menjaga iklim yang positif bagi investasi.

Dari penelitian ini ditemukan bahwa pertama, manajemen keamanan tidak hanya dilakukan oleh negara tetapi oleh private sector dalam hal ini perusahaan swasta. Artinya, negara bukan lagi satusatunya aktor yang penting dalam keamanan lokal (Avant, 2004). Kondisi tersebut dapat berimplikasi pada 'outsourcing kekerasan dan keamanan' yang dilakukan oleh aktor swasta (Avant, 2004; Singer, 2005). Akhirnya peran Pam Swakarsa yang diharapkan menjadi penyokong kepolisian untuk menciptakan keamanan dan ketertiban menjadi sulit dicapai ketika di dalamnya masuk kepentingan perusahaan yang pada satu waktu bersebrangan dengan masyarakat.

Kedua, jelasnya Paramiliter lahir sebagai bentuk kekerasan baru. Perusahaan membentuk paramiliter untuk pengamanan saat terjadi pertikaian tanah, namun paramiliter justru semakin mempertajam pertikaian tanah yang terjadi antara masyarakat tani dengan Perusahaan. Kehadiran paramiliter dan diamnya negara menyebabkan resistensi dan kemarahan masyarakat tani semakin besar. Peneliti seperti Hristov (2009) and Richani (2007) telah melihat paramilitarisme merupakan bagian dari negara para-institusional, dimana paramilitarisme harus dipahami dalam kaitannya dengan perkembangan kapitalisme dan neoliberalisme. Kegiatan paramiliter tidak hanya sebagai fenomena politik dan militer, tetapi juga sebagai suatu fenomena ekonomi, yang struktural dan dalam hubungan dua arah dengan negara. Bagi Hristov paramilitarisme mewakili jenis kekerasan khusus yang bersandar pada perpaduan kekuatan ekonomi dan politik, diorganisasi oleh kelas-kelas kapitalis dan lebih maju melalui dukungan lembagalembaga negara. Artinya, paramiliter terlibat dalam jenis pembangunan ekonomi tertentu yang menguntungkan kepentingan kelas para elit borjuis. Mereka telah mendorong suatu proses ekspansi ekonomi rente berdasarkan perampasan tanah besar misalnya. Perusahaan mencari peluang investasi, tanpa ragu mendapat manfaat dari peruntukan lahan. Sehingga banyak dijumpai praktik-praktik membayar kelompok paramiliter untuk membersihkan orang dari tanah mereka. Hubungan pamswakarsa dan perusahaan ini sering disebut sebagai penggambaran dari proses kekerasan akumulasi modal oleh perusahaan melalui kelompok paramiliter (Harvey, 2004).

Sejalan dengan pendapat Hristov dan Harvey tersebut di atas, penelitian ini menunjukan bagaimana sengketa yang berujung konflik berkaitan dengan kepentingan investasi negara. Negara cenderung memprioritaskan perusahaan, sedangkan kepentingan masyarakat kian terpinggirkan. Perusahaan yang memiliki modal besar memiliki pengaruh terhadap negara. Ia menjadi semakin kuat karena difasilitasi oleh negara dan militer. Hal ini tercermin setidaknya dari, pertama, tahun 1986 tanah yang tadinya diperuntukan untuk transmigrasi swakarsa menjadi bisa dimiliki dan dibeli oleh perusahaan. Desa yang bahkan sudah lama ada jauh sebelum transmigrasi juga menjadi tanah perusahaan. Perusahaan bahkan telah melakukan penanaman kelapa hibrida dan sawit sejak 1993 sebelum keluarnya HGU pada 30 Oktober 1995. Hal ini pun juga dibiarkan oleh pemerintah. Kedua, saat masyarakat menolak relokasi tahun 1990, negara dengan kekuatan militernya kemudian diturunkan. Ini menandakan bahwa untuk kepentingan perusahaan, negara secara tidak langsung memberi dukungan sampai dengan menggunakan kekerasan. Ketiga, kekerasan militer terulang kembali pada Mei 1993, saat Aparat TNI/BAKORSTANASDA memaksa masyarakat untuk menandatangani blanko kosong lalu menyerahkan uang Rp. 100.000 kepada warga. Keempat, pada 2 Oktober 2016 didatangkan batalyon Brimob dari Provinsi Lampung dan Sumatera Selatan dan menangkap 12 anggota Serikat Tani. 
Konflik ini telah memperlihatkan bagaimana kolaborasi yang baik antara perusahaan dan negara dalam memproduksi kekerasan terhadap masyarakat. Sejak awal sengketa muncul, kekerasan telah mengambil tempat antara lain saat upaya pemindahan warga terjadi di tahun 1991 dimana menjadi awal terjadi konflik. Pemindahan warga dikendalikan oleh sekelompok militer negara. Berdasarkan keterangan beberapa warga secara jelas melihat bagaimana kelompok militer berseragam mendatangi rumah warga dan secara paksa mengawal masyarakat 7 desa untuk pindah ke desa Indraloka II dan Bujug Agung Tulang Bawang. Bukan hanya sebagai alat intimidasi, beberapa oknum militer juga melakukan sejumlah kekerasan fisik dan menahan beberapa warga (Dokumen Serikat Tani, Agustus 2018).

Kekerasan yang secara langsung dilakukan negara terulang kembali, pada Mei 1993 aparat TNI/BAKORSTANASDA diturunkan ke desa Bujuk Agung dan Indera Loka II. Militer meminta masyarakat untuk menandatangani blanko kosong dan menyerahkan uang Rp. 100.000. bahkan ada warga yang ditendang dan dipukul dengan popor senjata. (Wawancara Tim Penelitian, September, 2018). Menurut keterangan Serikat tani Korban Gusuran (STKGB) terdapat sekurangnya total 10 jiwa meninggal dunia, diantaranya 8 orang warga, 1 orang anggota Pam Swakarsa, dan 1 orang satpol PP. ${ }^{2}$

Kekerasan kerap kali terjadi dalam konflik agraria. Kekerasan secara dramatis terkait dengan pertikaian tanah (Borras dan Ross 2007 dalam Jacobo Grajales,

\footnotetext{
${ }^{2}$ konflik antara masyarakat di 9 desa dengan PT. BNIL yang dibantu oleh pemerintah, polisi dan TNI telah menyebabkan korban meninggal dunia atas: (1) Kliwon; (2) Petrus; (3) Ismail; (4) Raun; (5) Made Game; (6) Santosa; (7) Salim; (8) Nyoman Suarte. Beberapa warga masyarakat dianiaya dan diantaranya mengalami cacat permanen. Warga
}

2011:771). Kasus antara PT BNIL dengan warga tani adalah permasalahan sengketa tanah. Dalam kasus ini, kekerasan beriringan dengan perampasan tanah, penggusuran dan pemaksaan. Perampasan tanah yang selama ini ditempati warga seketika menjadi dimiliki oleh perusahaan dengan keluarnya HGU dari BPN. Masyarakat sebagian menganggap diri mereka memiliki tanah tersebut dan membeli tanah tersebut. Salah satu kelemahan warga adalah tidak memiliki bukti kepemilikan atas lahan tersebut. Kekeliruan pertama, negara alih-alih menyelesaikan permasalahan dengan kedua belah pihak, namun justru tergesa-gesa memutuskan memberikan hak izin usaha dan tanah kepada PT BNIL. Kekeliruan berikutnya, negara kemudian menggunakan kekerasan dan melakukan penggusuran paksa tanpa pembicaraan ganti rugi yang jelas sebelumnya.

Pada sebelum era 1990, kekerasan secara nyata dilakukan oleh negara melalui militer. Kepentingan akan perusahaan dan investasi mengalahkan kewajiban melindungi hak asasi warga negara. Hal ini cukup beralasan mengingat saat sebelum 1990, Indonesia yang pada saat itu di masa Orde Baru memang menerapkan azas Dwi Fungsi ABRI. Negara menempatkan militer memiliki peran ganda baik dalam bidang pertahanan maupun bidang sipil yakni politik, ekonomi, sosial, budaya, dan kamtibmas. Keberadaan militer menjadi cermin keberadaaan negara, terutama saat itu pemerintahan Soeharto memang dikenal banyak menggunakan instrumen militer untuk mendukung kebijakan pemerintah.

Pasca 1990, saat reformasi bergulir melalui reformasi militer dan pemisahan

yang mengalami penganiayaan oleh aparat adalah: (1) Sidal; (2) Mulyadi/Yayak; (3) Wiji; (4) Mujianto; (5) Nawan; (6) Supadi; (7) Jaimin; (8) Muhadi; (9) Mursid; (10) Asep; (11) Darsoni; (12) Jamaludin; (13) Fauzi; (14) Made Sudiarte; (15) Isak; (16) Yanto; (17) Maridi; (18) Pendi. 
antara TNI-POLRI menempatkan posisi militer jauh dari arena politik negara, bahkan negara dituntut untuk menjauhi sikap otoritarian dan represif demi menjaga konsistensi terhadap demokrasi. Hal ini turut mempengaruhi situasi konflik. Kekerasan yang dihadapi oleh masyarakat salah satunya beralih dari kekerasan militer kepada kekerasan paramiliter yang diambil alih oleh perusahaan melalui Pam Swakarsa.

Pam Swakarsa semacam paramiliter bentukan perusahaan yang sebetulnya lebih dekat kepada mobilisasi masa ini sering membawa senjata tajam (Wawancara Tim Penelitian, 5 September 2018). Meskipun, tidak ditemukan kekerasan serius yang dilakukan Pam swakarsa terhadap warga, namun salah satu peristiwa memperlihatkan bagaimana kerjasama telah dibangun oleh Pam swakarsa, Perusahaan, dan Negara dalam menghadapi masyarakat. Pasca reformasi Indonesia, kekerasan terjadi dalam peristiwa bentrok antara Pam Swakarsa PT X dengan Serikat Tani terjadi pada 1 Oktober 2016. Ketiadaan penjagaan kepolisian sebetulnya menjadi faktor penting, polisi yang mestinya ikut bertanggung jawab dalam penjagaan dapat bertindak lebih netral namun kepolisian menyalahkan tindakan massa Serikat Tani yang menghancurkan kemah dan merusak kendaraan bermotor Pam Swakarsa (KPA, 2016).

Pada tanggal 2 Oktober, pasukan Brimob dalam jumlah besar didatangkan lengkap dengan water canon, gas air mata, senapan laras panjang, kawat berduri dan melakukan pengusiran terhadap Massa Serikat Tani sampai dengan mencari pimpinan Serikat Tani. Aparat juga tidak segan melakukan tindakan yang lebih represif terhadap warga seperti menjebol pintu rumah seorang warga di RK IV, Bujuk Agung untuk menemukan anggota Serikat Tani pada 3 Oktober dan menghancurkan tenda persembunyian warga bahkan menahan 6 orang anggota Serikat Tani.
Paramilitarisme merupakan salah satu representasi dari paradigma yang mengakui peran aktor non-negara dalam konflik. Tidak hanya dalam bentuk satpam, atau organisasi masyarakat, fenomena pam swakarsa juga menjadi salah satu bentuk yang mengarah pada paramiliterisme. Sebagaimana, tentara pretorian yang biasanya terbentuk untuk melindungi pemilik modal dan bangsawan (Amos Permutler, 1985), maka pam swakarsa terlihat cenderung lahir atas kepentingan pemilik modal dalam hal ini perusahaan. Peran paramiliter hampir selalu selaras dengan status quo di tingkat lokal terkait mengenai masalah modal dan ekonomi. Karena status quo perusahaan, negara sering mentoleransi alokasi kekerasan mereka. Perusahaan menjadi kekuatan yang terus tumbuh dalam isu-isu tata kelola pemerintahan (good governance).

\section{KESIMPULAN}

Provinsi Lampung menjadi salah satu provinsi yang kerap kali menghadapi konflik agraria. Konflik agraria ini umumnya berawal dari sengketa tanah antara Perusahaan dan warga masyarakat. Salah satu konflik yang menarik terjadi pada tahun 2016. Konflik ini diperburuk oleh mobilisasi massa dalam bentuk Pam swakarsa. Pam swakarsa dapat diklasifikasikan sebagai bentuk diantara polisi sipil dan paramiliter karena memiliki tingkat kemampuan militer, walaupun secara tegas ia bukan cabang dari suatu angkatan bersenjata. Pam Swakarsa berdasarkan definisinya dalam aturan PP RI No 43 tahun 2012 merupakan bentuk group yang membantu menciptakan keamanan, dibina secara khusus contohnya satpam.

Ironisnya, Pam Swakarsa yang terlibat dalam konflik nyatanya bukan dalam bentuk satpam semata melainkan Perusahaan membuat kelompok Pam Swakarsa jenis lain yang bersifat reaktif dan spontan. Pam Swakarsa dibentuk saat terjadi konflik. Pam Swakarsa yang 
diharapkan dapat membantu membentuk keamanan, justru menjadi actor baru yang muncul dalam konflik agrarian. Kepolisian pernah menjanjikan untuk membubarkan Pam Swakarsa, namun belum sempat dilaksanakan konflik terbuka akhirnya terjadi antara masyarakat, Serikat Tani Korban Gusuran dengan Pam Swakarsa.

Sengketa antara perusahaan dan masyarakat sulit diselesaikan karena ia berkaitan dengan kepentingan investasi negara. Perusahaan menjadi semakin kuat karena difasilitasi oleh negara dan militer, terutama pada sebelum tahun 1990an. Sedangkan pada pasca reformasi tahun 1990, pengembalian fungsi TNI dan pemisahan POLRI dari TNI, menyebabkan kekerasan bergeser dari negara kepada perusahaan.

Negara bukan lagi satu-satunya aktor yang penting dalam keamanan. Pam Swakarsa yang dibentuk perusahaan berpeluang melahirkan bentuk baru kekerasan. Kelompok ini penting dalam melindungi aset sekutu (perusahaan) mereka dari tuntutan petani akan hak lahan mereka. Paramiliter menggunakan kekerasan untuk memukul mundur warga. Hingga pada Oktober 2016, paramiliter bentukan perusahaan berpartisipasi dalam menggunakan kekerasan bahkan bentrok dengan masyarakat tani. Hal ini tentu bukan hal yang diharapkan sebagaimana PP RI No 43 tahun 2012 Bab 2 Pasal 6 yang disebutkan secara khusus bahwa pam swakarsa bertugas menjaga keamanan dan ketertiban di lingkungannya secara swakarsa guna mencegah terjadinya gangguan keamanan dan ketertiban.

Meskipun dikategorikan bukan satpam, Pam Swakarsa yang ditugaskan oleh Perusahaan saat eskalasi konflik tetap menjadi tanggung jawab negara, karena negara melalui aturannya telah memberi celah kepada Perusahaan atau instansi lainnya untuk membentuk dan membuat Paramiliter. Negara juga bertanggung jawab atas status tanah dan ketergesaan dalam memberikan HGU kepada Perusahaan.

\section{Saran}

Seiring dengan fenomena globalisasi, perkembangan industri menjadi semakin cepat dan massif. Negara di satu sisi, diharapkan dapat membangun pertumbuhan ekonomi dan bersaing dengan negara lainnya di dunia internasional. Namun, di sisi lain, negara seringkali harus dihadapkan pada pilihan-pilihan antara menjamin hak keamanan warga negara atau memberi kebebasan bersekspresi, menjamin ekonomi atau keamanan warga negara, sampai harus memilih antara kepentingan investasi atau hak masyarakat.

Hal ini menghadirkan sebuah pilihan rumit bagi negara. Jika melihat lebih jauh, sesungguhnya negara tidak dapat memilih. Sebab, bagaimana sebuah kepentingan investasi dan perusahaan dapat diprioritaskan atas nama pertumbuhan ekonomi, jika sebetulnya ujung pertumbuhan ekonomi adalah tercapainya kesejahteraan masyarakat. Masyarakat di Tulang Bawang merupakan masyarakat miskin yang mestinya menjadi tanggung jawab negara, sejalan dengan pasal 34 UUD 1945 adalah termasuk tugas negara, memberikan akses ekonomi bagi warganya. Akibat penggusuran, negara justru turut bertanggung jawab dalam memiskinkan penduduk (korban). Negara juga terlalu cepat memutuskan tanpa dialog dengan warga mengenai pengambilalihan lahan dan penetapan status lahan. Sehingga, atas nama investasi, di dalam kasus ini, negara secara tidak langsung telah berkontribusi terhadap pemiskinan warga/masyarakat.

Beberapa hal sebetulnya bisa dilakukan oleh negara. Pertama, negara mestinya lebih serius dan mulai melakukan penataan adminsitratif yang sungguh-sungguh bagi status tanah hak milik di berbagai wilayah di Indonesia. Lebih baik tentunya pemerintah dapat memberikan tanah bagi warga miskin, terutama petani yang 
hidupnya bergantung pada lahan. Kedua, negara dapat menambahkan aturan secara tegas terhadap bentuk-bentuk Pam Swakarsa yang diperbolehkan. Ketiga, negara harus bertindak tegas terhadap jenis mobilisasi massa apapun meski itu adalah bentukan perusahaan. Keempat, membuat aturan sedemikian rupa mengenai hubungan hak dan kewajiban perusahaan terhadap negara dan masyarakat di Indonesia, semisal mengenai Corporate Social Responsibility (CSR). Di beberapa wilayah, masyarakat sering mengeluhkan masalah CSR dari perusahaan. Besaran dana CSR pada akhirnya akan memengaruhi cara pandang masyarakat. Melalui kegiatan CSR, perusahaan juga dapat menjalin komunikasi dan dekat dengan masyarakat.

Penelitian yang menarik dapat dikembangkan dari riset ini di antaranya ialah mengenai paramiliter yang dibuat oleh beberapa organisasi masyarakat di Indonesia atau mengenai dampak dana CSR terhadap cara pandang masyarakat sekitar.

\section{DAFTAR PUSTAKA}

Andrade, John, World Police and Paramilitary Forces (New York: Stocton Press, 1985), hlm. ix.

Brown, C., \& Ainley, K. (2009). Understanding International Relations. London, UK: Palgrave Macmillan.

Finer, Samuel E. 1976. The Man on Horseback: The Role of the Military in Politics. New Brunswick: Transaction Publishers.

Gerivarth, Robert dan John Horne. 2012. War in Peace: Paramilitary Violence in Europe after the Great War. United Kingdom: Oxford University Press.

Kolip, Usman dan Elly M. Setiadi. 2010.
Pengantar Sosiologi. Jakarta: Kencana Prenada Media Group.

Layton-Henry, Z. and P. Burnham, K. Gilland, W. Grant. 2004. Research Methods in Politics, Palgrave Macmillan, New York.

Perlmutter, Amos. 1985. Militer dan Politik. Jakarta: Rajawali Press.sepiRalf Dahrendorf. 1986. Konflik dan Konflik dalam Masyarakat Industri: sebuah Analisis Kritik. Jakarta: Rajawali Press.is[ي-p]

Yin, R.K. 2003, Case Study Research: Design and Methods, $3^{\text {rd }}$ edn, Sage Publications, London.

\section{Jurnal:}

Bahar, Safroedin. 2000. Kajian Awal Tentang Keterkaitan Pasukan Paramiliterdan Militer dengan Faham Militerisme dan Fasisme di Indonesia. Jurnal Ketahanan Nasional, Vol. V. No. 3, hlm. 67.

Bennett, J. (2002). Multinational corporations, Social Responsibility and Conflict. Journal of International Affairs, 55, 393-410.

Collier, David. 2011. "Understanding Process Tracing", Political Science and Politics, Vol. 44 No. 4, hlm. 824.

Feil, M. (2002). Global Governance and Corporate Responsibility in Conflict Zones. Basingstoke, UK: Palgrave Macmillan.

Friedman, M. (1970). The Social Responsibility of Business is to Increase its Profits. The New York Times Magazine, September 13, 1970. Retrieved from http://www.colorado.edu/studentgr oups/libertarians/issues/friedman- 
soc-resp-business.html

Grajales, Jacobo. The rifle and the title: paramilitary violence, land grab and land control in Colombia. The Journal of Peasant Studies Vol. 38, No. 4, October 2011, 771-792. Hal 771.

Harvey, D. (2004). The 'New' Imperialism: Accumulation by Dispossession. Socialist Register, 40, 63-87.

Haufler, V. (2008). MNCs and the International Community: Conflict, Conflict Prevention and the Privatization of Diplomacy. Palgrave MacMillan UK.

Hristov, J. (2009). Legalizing the illegal: Paramilitarism in Colombia's 'postparamilitary' era. NACLA Report on the Americas, 42, 12-39.

Kappeler, Victor E. and Peter B. Kraska.1997. Militarizing American Police: The Rise and Normalization of Paramilitary Units. Social Problems Journal, vol. 44, No. 1 (Feb., 1997), pp 1-18, hlm. 2.

M.A., Rahim. 2002. Toward a Theory of Managing Original Conflict. The International Journal of Conflict Management, hlm. 16.

McDonald, Matt and Lee Wilson, 2017. 'Trouble in paradise: Contesting security in Bali', Security Dialogue, Vol. 48, issue: 3, pp. 241-258.

Richani, N. (2007). Caudillos and the Colombian State: fragmented sovereignty, the war system and the privatization of counterinsurgency in Colombia. Third World Quarterly, 28, 403-417.

Wahab, Oki Hajiansyah. 2013. 'Pengabaian Hak-Hak Konstitusional dalam Perspektif Keadilan (Studi Kasus
Warga Moro-Moro Register 45, Kabupaten Mesuji Lampung), Jurnal IUS: Kajian Hukum dan Keadilan, vol. 1, No 1, hlm. 15-31.

\section{Internet:}

Avant, D. (2004). The Privatization of Security and Change in the Control of Force. International Studies Perspective. 153-157. Retrieved from http://psm.du.edu/media/docume nts/related_resources/avant_priva tization_of_security_and_ch ange_in_control_of_force.pdf

Department of Defense of the United States of America, Department of Defense Dictionary of Military and Associated Terms, Joint Chiefs of Staff, USA, as of September 2018, hlm. 179; tersedia juga di http://www.jcs.mil/Portals/36/Docu ments/Doctrine/pubs/dictionary.pdf diakses pada 11 November 2018.

Direktorat Jenderal Politik dan Pemerintahan Umum, Kementerian Dalam Negeri RI, 'Data Konflik Sosial' tersedia di http://kesbangpol.kemendagri.go.id /index.php/subblog/pages/2015/350 /Da ta-Konflik-Sosial diakses pada 1 Februari 2018.

http://newslampungterkini.com/news/1374 0/pam-swakarsa-bersenjata-apirakitan-dicomot-polisi.html

http://www.kpa.or.id/news/wpcontent/uploads/2016/10/Kronologi s-dan-Latar-Belakang-Konflik-PTBNIL.pdf

https://lampungpro.com/post/5846/bakutembak-antara-warga-dan-pamswakarsa-bupati-mesuji-mintasemua-tenang 
https://nasional.kompas.com/read/2011/12/ 21/17361979/Tragedi.Mesuji.Dua. Pam.Swakarsa.Dipenggal

Kompas.com, 'Kompleksitas Konflik Lampung', tersedia di http://nasional.kompas.com/read/2 012/11/04/08580419/Kompleksitas .Kon flik.Lampung diakses pada 1 Februari 2018.

Kompas.com, 'Perkara Konflik Agraria di Lampung Menumpuk', tersedia di http://nasional.kompas.com/read/2 012/05/28/2014289/perkara.konflik .agr aria.di.lampung.menumpuk diakses pada 1 Februari 2018.

Konsorsium Pembaruan Agraria (KPA), 'KPA Launching Catatan Akhir Tahun 2017 ' tersedia di http://www.kpa.or.id/news/blog/kp a-launching-catatan- akhir-tahun2017/ diakses pada 1 Februari 2018.

Sindre, Gyda Marås, 'Violence and Democracy: Indonesia's Paramilitary Puzzle', Tesis, Departemen Ilmu Politik, University of Oslo, tersedia di https://www.duo.uio.no/handle/108 52/13765 diakses pada 21 Oktober 2018.

Singer, P.W. (2005). Outsourcing War. Foreign Affairs, 82, March/April 2005. Retrieved from https://www.foreignaffairs.com/arti cles/2005-03-01/outsourcing-war

Viva News, "Pam Swakarsa di Mesuji Minta dibubarkan" diakses pada 10 November 2018 https://www.viva.co.id/berita/nasio nal/272851-bubarkan-pamswakarsa-di-mesuji

\section{Undang-undang:}

Undang-undang Nomor 5 Tahun 1960 tentang Pokok-pokok Agraria (UUPA).

Undang-undang RI No. 2 Tahun 2002 tentang Kepolisian Negara Republik Indonesia.

\section{Wawancara:}

Wawancara dengan Kapolres Tulang Bawang, AKBP Syaiful Wahyudi, di Mapolres Tulang Bawang, Senin, 5 November 2018.

Wawancara dengan Bapak X, BapakY, dan Bapak Z, anggota dan mantan anggota pamswakarsa di PT BNIL, di Tulang Bawang, Kamis, 20 September 2018.

Wawancara dengan STKGB dan masyarakat korban gusuran PT BNIL, di Tulang Bawang, di Tulang Bawang, Kamis, 20 September 2018.

Wawancara dengan Bapak A, Biro Hukum Pemerintah Kabupaten Tulang Bawang, di Kantor Bupati Tulang Bawang, Senin, 5 November 2018. 
